\title{
Microglandular hyperplasia of the cervix: frequency in cone specimens, histological patterns, clinical aspects and immunohistochemical markers for differential diagnosis with adenocarcinoma
}

\author{
Hiperplasia microglandular da endocérvice: freqüência em peças de conização, padrões morfológicos, aspectos \\ clínicos e marcadores imuno-histoquímicos no diagnóstico diferencial com o adenocarcinoma
}

Inês Liguori Padrão'; Liliana Aparecida Lucci De Angelo Andrade²

\begin{abstract}
key words abstract
Uterine cervix

Although endocervical microglandular hyperplasia (MGH) is a common diagnosis, it can be confused with adenocarcinoma (ACa), mainly of the clear cell type. Objectives: Evaluate the frequency of MGH diagnosis in conization specimens, their histological patterns and characterize the differential diagnosis between $\mathrm{MGH}$ and $\mathrm{ACa}$ through immunohistochemical markers, as well as some clinical aspects. Methods: We reviewed 223 cervical cones and $50 \mathrm{ACa}$ in cervical biopsies in order to: 1) assess the frequency of $\mathrm{MGH}$ in cones; 2) verify immunohistochemical expression of $\mathrm{p} 53$, carcinoembryonic antigen (CEA) and Ki67 in both lesions; 3 ) correlate the findings to age, parity and hormonal status. Results: We found 35 cases of MGH (15.7\%), of the following patterns: 21 glandular (60\%); 7 reticular (20\%); 6 trabecular $(17.1 \%)$ and one solid (2.8\%). Average age was 36 years and mean parity was three children. Of the MGH patients, $51.42 \%$ were pregnant or made use of some hormonal therapy. ACa occurred in older patients (mean: 53 years), multiparous and with no hormonal history. CEA was negative in $\mathrm{MGH}$ and positive in $62 \%$ of $\mathrm{ACa}$. Ki67 was weakly positive (5\%-10\% stained nuclei) in $8.6 \%$ of $\mathrm{MGH}$ and strong ( $>40 \%$ stained nuclei) in $80 \%$ of $\mathrm{ACa}$. p53 expression was negative in $\mathrm{MGH}$ and only present in $10 \%$ of $\mathrm{ACa}$. Conclusions: MGH was common in cones, mainly in young women. Half of the cases were associated with hormonal therapy or pregnancy. CEA and Ki67 were useful but p53 expression was not important for the differential diagnosis with adenocarcinoma.
\end{abstract}

resumo

Embora a hiperplasia microglandular da endocérvice (MGH) seja um diagnóstico freqüente, algumas vezes pode ser confundida com adenocarcinoma ( $A C a)$, principalmente de células claras. Objetivos: Avaliar a freqüência da MGH em cones de colo uterino, seus padrões histológicos e o diagnóstico diferencial entre MGH e ACa, através de marcadores imuno-histoquímicos e de alguns aspectos clínicos. Métodos: Foram revisados 223 cones, bem como 50 biópsias cervicais com o diagnóstico de adenocarcioma para: 1) verificar a freqüência de MGH nos cones; 2) avaliar a expressão de p53, antígeno carcinoembrionário (CEA) e Ki67 nas lesões; 3) correlacionar as lesões com idade, paridade e estado hormonal. Resultados: MGH ocorreu em 35 cones $(15,7 \%)$, com os padrões glandular (21 [60\%]); reticular (7 [20\%]); trabecular (6 [17,1\%]) e sólido (um [2,8\%]). A média de idade foi 36 anos e de paridade, três filhos; $51,42 \%$ estavam grávidas ou usavam terapia hormonal. O ACa ocorreu em pacientes mais velhas (média: 53 anos), multiparas e sem história hormonal. CEA foi negativo em todas MGH e positivo em $62 \%$ dos ACa. Ki67 apresentou reatividade baixa (5\% a 10\% dos núcleos corados) em 8,6\% das MGH e alta (> 40\% dos núcleos corados) em $80 \%$ dos ACa. p53 foi negativo na MGH e positivo em apenas $10 \%$ dos $A C a$. Conclusão: MGH foi freqüentemente encontrada em cones, principalmente em jovens, sendo metade dos casos associada a terapia hormonal ou gravidez. As expressões do CEA e do Ki67 foram importantes no diagnóstico de ACa, porém o p53 não contribuiu para diferenciar as lesões. unitermos

Colo uterino

Hiperplasia microglandular da

endocérvice

Diagnóstico

Imuno-histoquimica

Adenocarcinoma

1. Mestre em Ciências Médicas, área de Anatomia Patológica, Faculdade de Ciências Médicas da Universidade Estadual de Campinas (FCM/UNICAMP).

2. Professora-associada do Departamento de Anatomia Patológica, Faculdade de Ciências Médicas da UNICAMP.

Trabalho referente à dissertação de mestrado Hiperplasia microglandular da endocérvice: estudo dos aspectos morfológicos e da expressão do p53, CEA e Ki-67 no diagnóstico diferencial com o adenocarcinoma, defendida por Inês Liguori Padrão em 2002, na FCM/UNICAMP. 


\section{Introduction}

The non-neoplastic glandular lesions of the cervix make up a group of hyperplastic alterations occurring in the endocervix and are generally incidental microscopic findings, which accompany other important diagnoses. Although they may show architectural or cytological abnormal aspects, they are different from malignant tumors, therefore it is fundamental that pathologists familiarize themselves with them so as not to diagnose them as adenocarcinoma (ACa) or other pre-neoplastic lesions ${ }^{(31,35,36)}$.

Endocervical microglandular hyperplasia $(\mathrm{MGH})$ is one of those lesions. It was first described by Taylor $\mathrm{HB}$ et al.(26) in 1967, and is generally found in young women. The etiology of MGH seems to be associated to the effects of endogenous hormones, either to those in pregnancy or to iatrogenic effects of prolonged hormone therapy, combined with progesterone-estrogen or with gestagens used in either gynecological therapeutic treatment or as a contraceptive ${ }^{(6,11,18,26,32)}$. However, it can also be found in post-menopausal women with or without a history of hormone replacement therapy ${ }^{(3)}$.

Macroscopically, it can be like erosion or a cervical polyp or even as a friable polyp ${ }^{(18)}$. Microscopically, it is characterized by complex glandular proliferation, which is associated to reserve cell hyperplasia and squamous metaplasia ${ }^{(5,13,31,32)}$. It can be found in one or multiple foci, on the surface of the endocervical mucosa or in glandular areas. It is found in biopsy material, conization of the cervix or in hysterectomies, and sometimes it can be mistaken for cervical adenocarcinoma ${ }^{(12,18,26)}$.

Based on literature $\mathrm{MGH}^{(5-7,18,31,34,35)}$ is made up of glandular spaces, and is generally small and variable in shape (either round or irregular, either small or cystically dilated). The glandular spaces seem to mold into each other giving a cribriform aspect to the microscopic image, also determined by the very evident vacuolization. The number of vacuolated cells can be so important that MGH can be mistaken for clear cell type adenocarcinoma. The glands form cysts covered by glandular epithelium that protrudes into the lumina forming bridges; these cystic cavities contain fluid mucus where neutrophils, macrophages and nuclear debris are immersed. The glandular epithelium is columnar, resembling the normal endocervical epithelium, or cubed, flattened, frequently without atypical cell morphology, spread out either in a single layer or showing a pseudo-stratified aspect. The oval or elongated nucleus presents granular chromatin and, at times, a prominent nucleolus; however, mitoses are rare. The cytoplasm is granular and vacuolated and in some cases shows a quantity of mucus, which repels the nucleus to the border, imitating signet-ring cells. The glandular formations can be surrounded by a cluster of reserve cells or, more frequently, by immature metaplastic epithelium cells, which are the results of the reserve cells transformation and can present some cellular atypia. The stroma is loose and edematous, well-vascularized due to the capillary network, and shows either an acute or a chronic inflammatory process next to small areas of hemorrhage. Fibrosis or hyaline areas are found in polypoid lesions.

Four histological patterns ${ }^{(6)}$ can be identified: 1) glandular; 2) reticular; 3) trabecular; 4) solid (Figure).

The glandular subtype is more frequent and represents the fundamental and typical structure of $\mathrm{MGH}$. The reticular one is characterized by the accumulation of intercellular mucous, which is associated to stromal edema and splits the glandular epithelium, placing the cells in crooked lines. In the trabecular subtype, the proliferation of cells in layers or solid trabecula limits the space with mucus, cellular debris and inflammatory cells, thus giving a false aspect of infiltration, which can be mistaken for malignancy. The solid subtype, less common, shows increased cellularity with either no glandular formation or small rare glandular lumina, very little stroma, a homogeneous hyperplastic and monomorphous aspect. This is the most difficult pattern to differentiate from adenocarcinoma.

The morphological aspects usually characterize the majority of the lesions. However, at times, there are cases that are difficult to diagnose, thus a marker that can clearly differentiate a lesion from an ACa must be looked for ${ }^{(4,24)}$.

Protein $\mathrm{p} 53$ expression, the increased cellular proliferation rate measured by Ki67 expression and cytoplasmatic positivity for the carcinoembryonic antigen (CEA) are markers for either in situ or invasive ACa. Some authors suggest the use of immunohistochemical reactions for the differential diagnosis between $\mathrm{MGH}$ and $\mathrm{ACa}$, although the number of studied cases is small and the interpretation of the data is not always decisive $e^{(4,19,21,23,25,30,33)}$.

The aims of this study, by means of a histological review of 223 cones of the cervix, are: 1) evaluate the frequency of $\mathrm{MGH}$ diagnosis in cone specimens; 2) characterize morphologically the different histological patterns of $\mathrm{MGH}$; 3) verify the immunohistochemical expression of this lesion to CEA, p53 and Ki67 markers, comparing it to ACa; 4) describe the clinical aspects of the patients (age, parity and use of contraceptive hormone therapy or hormone therapy for other reasons) in both conditions. 


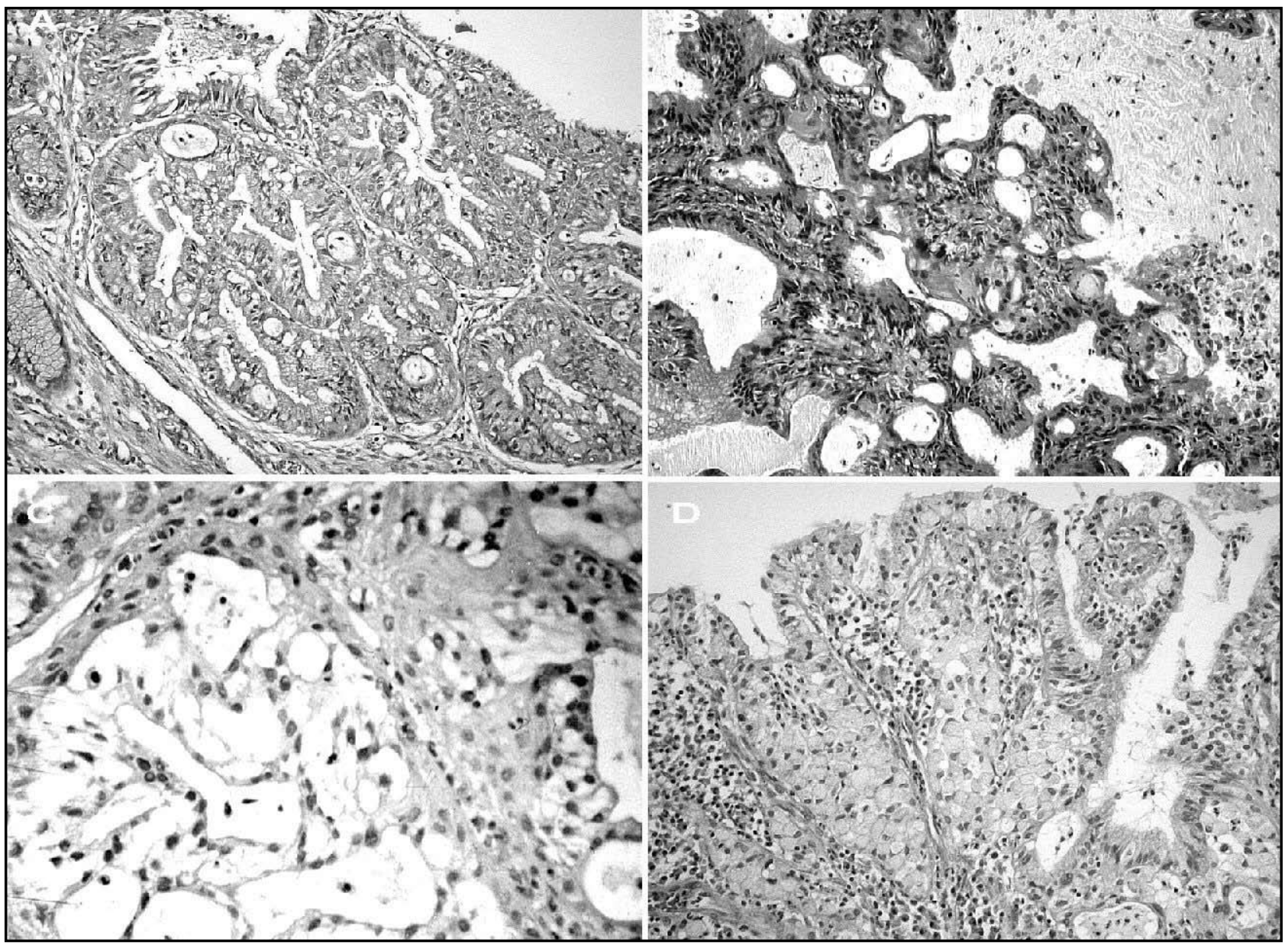

Figure - Microglandular hyperplasia (MGH) histological patterns. A: glandular type (the most common); B: trabecular; C: reticular; D: solid

\section{Materials and methods}

This investigation was approved by our institutional medical ethics committee. In order to diagnose $\mathrm{MGH}$, hematoxylin and eosin (HE) stained slides, from 223 cones of the cervix, taken during a period of four years, were reviewed from the files of the Pathology Department Laboratory, as well as 50 cervical biopsies with the diagnosis of adenocarcinoma (ACa).

The endocervical MGH cases were classified according to the four histological patterns described: glandular, trabecular, reticular and solid.

After the morphological characterization, $\mathrm{MGH}$ and $\mathrm{ACa}$ cases were evaluated according to the immunohistochemical reactions for CEA, p53 and Ki67 markers. For this, the best blocks were selected and new sections were made on the silanized slides. The antigenic recovery was carried out in a vapor pan. Specific primary antibodies CEA monoclonal (clone A5B7, Dakopatts, Carpinteria, USA), p53 monoclonal (DO-7, Dakopatts, Carpinteria, USA) and Ki67 (KiS5 monoclonal antibody, Dakopatts, Carpinteria,
USA) were used in $1 / 20,1 / 100$ and $1 / 50$ concentrations, respectively, and as a secondary antibody, the reaction amplifier Envision (Dakopatts, Carpinteria, USA) was used. Ki67 immunoreactivity is confined to the nucleus in division activity and marks a cellular cycle protein in phases S, G2 and $\mathrm{M}$, and therefore it is a growth or cellular proliferation fraction marker. The reading of the reactions was carried out according to the following procedures ${ }^{(4)}$ :

- p53 - positive when the number of intensely stained nuclei was larger than $10 \%$ in the fragment;

- Ki67 - negative when less than 5\% of the nuclei were dyed; low reactivity from $5 \%$ to $10 \%$ of the stained nuclei; high reactivity when the nuclear staining rate exceeded $40 \%$;

- CEA - positive when the cytoplasm presented itself partially or totally stained.

Through the gathering of the registers, the clinical characteristics of patients were evaluated: age, parity, use of oral contraceptives, other forms of hormone therapy and pregnancy. 


\section{Results}

\section{Frequency of cones with MGH}

From the 223 studied cones, MGH was found in 35 cases $(15.7 \%)$, while the lesion varied from small foci to larger and sometimes multifocal lesions.

\section{Frequency of the different histological patterns of $\mathbf{M G H}$}

In terms of MGH subtypes, some cases showed concomitancy of two or, however rarely, three types of $\mathrm{MGH}$, particularly in multifocal cases, with the predominance of one of them. For each MGH case, the predominant type was marked. Thus, 21 (60\%) of the cases were glandular; seven (20\%) were reticular; six (17.14\%) were trabecular and the solid type was found in only one sample (2.86\%).

\section{Clinical characteristics}

- Age: the age of the MCH patients varied from 16 to 69 , with a mean of 36 years and for ACa from 26 to 79 , with a mean of 53 years.

- Obstetric and hormonal profile: a) MGH patients: parity varied from 0 to 11 children with an average of six children. The contraceptive method mostly used among the MGH patients was oral contraceptives in 12 cases (34.28\%), followed by the IUD in three cases ( $8.57 \%)$, tubal ligation in three cases (8.57\%) and condom in one case (2.85\%). One patient $(2.85 \%)$ used injectable progestins for contraceptive treatment, eight patients (22.85\%) did not use any contraceptive method, two $(5.71 \%)$ were in the perimenopause and two (5.71\%) were pregnant. So, the concomitancy of endogenous or exogenous hormonal events related to $\mathrm{MGH}$ occurred in 18 cases $(51.42 \%)$ : two pregnant patients $(5.71 \%)$, three with a history of recent delivery $(8.57 \%)$, one under the effect of progestins (2.85\%) and 12 using oral contraceptives (34.28\%); b) ACa patients: parity varied from 0 to 14 , average of 4.4 children. The contraceptive methods used in this group were tubal ligation (30\%), oral contraceptives (11.36\%) and IUD (4.54\%). Two patients were pregnant and $48 \%$ did not use any contraceptive method.

- The most common diagnosis on cones specimens was cervical intraepithelial neoplasia (CIN) and the frequency of the main lesions associated to MGH is shown in Table 1.

- Adenocarcinoma: the histological types and grades of the 50 cervical biopsies with adenocarcinoma are shown in Table 2. The usual type of mucinous adenocarcinoma was the most common histological type.

\section{Immunohistochemistry}

The immunohistochemical study on the $35 \mathrm{MGH}$ cases showed negativity for all of the cases with p53 and CEA. Ki67 presented only low positivity ( $5 \%$ to $10 \%$ of stained nuclei) in three cases (8.6\%). Otherwise, in $\mathrm{ACa}$, CEA was expressed in $62 \%$, most of them with mucinous differentiation, independent of the histological grade (Table 2). Ki67 was strong ( $>40 \%$ stained nuclei) in $80 \%$ (Table 2) and p53 was focally positive in only $10 \%$ of the cases (Table 3).

\section{Discussion}

$\mathrm{MGH}$ is an incidental finding in conization, presenting a $15.7 \%$ incidence in this study. It was found in greater frequency in young women with mean age of 36 years. In this population, the patients' age varied between 16 and 69 years, with a greater number of cases between the ages of 27 and 46 years. These data are in agreement with literature, which states the mean age for $\mathrm{MGH}$ cases to be between 25 and 37 years $(3,6,11,18)$.

MGH was associated with patients under either endogenous or exogenous hormone effects in $51.42 \%$ of the studied cases. It is a known fact that cervix mucosa responds to estrogen hormones ${ }^{(8,10,18,20,22)}$ with a proliferation of the endocervical columnar cells. The progestinic stimulation increases the consistency of the mucous, making it thick. The maintenance of the histological modifications of the cervix induced by progesterone appears not to depend on the continuity of the use of this hormone ${ }^{(3,11)}$. In the $60^{\prime}$ 's and 70 's, oral contraceptive users presented a high percentage of $\mathrm{MGH}$ in the studied populations, reaching rates of over $90 \%(18,26,32,36)$. The first oral contraceptives had much higher doses of steroids, but this fact has been changed by the pharmaceutical laboratories throughout the last 40 years. The chemical modifications in these substances allowed a drastic reduction in the quantity of gestagens used.

The literature on $\mathrm{MGH}$ has shown that there is a reduction in the concomitance of oral contraceptive use, as described by Chumas et al. ${ }^{(3)}$, in 1985: in 43 cases of MGH 45\% used oral contraceptives. However, Daniele et al. ${ }^{(6)}$, in 1993, described 28 cases of $\mathrm{MGH}$, of which 11 (39.28\%) were oral contraceptive users and five (17.85\%) were pregnant, with a total of $57.13 \%$ of the patients under 
Table 1

\section{Distribution of the main lesions in the 223 studied cones and their association to MGH}

\begin{tabular}{lcccc}
\hline Main diagnosis & Number of diagnosis & $\%$ & MGH & $\%$ \\
\hline CIN & 153 & 68.56 & 25 & 11.21 \\
Microinvasive Ca & 28 & 12.55 & 6 & 2.69 \\
Squamous cell Ca & 10 & 4.48 & 1 & 0.44 \\
Adenocarcinoma & 2 & 0.89 & 1 & 0.44 \\
No neoplasia & 30 & 13.42 & 2 & 0.89 \\
Total & 223 & 100 & 35 & 15.7 \\
\hline
\end{tabular}

Table 2

Cervical biopsies with the diagnosis of adenocarcinoma (ACa): histological types, grades and

\begin{tabular}{|c|c|c|c|c|}
\hline Histological type and grade & $\mathrm{N}(\%)$ & $\mathrm{CEA}+(\%)$ & $\begin{array}{c}\text { Ki67+ }(\%) \\
>40 \% \text { stained nuclei }(\%)\end{array}$ & $\mathrm{p} 53(\%)$ \\
\hline Well differentiated usual mucinous adenocarcinoma & $15(30)$ & $9(60)$ & $12(80)$ & $3(6)$ \\
\hline $\begin{array}{l}\text { Moderately differentiated usual mucinous } \\
\text { adenocarcinoma }\end{array}$ & $15(30)$ & $10(67)$ & $13(87)$ & 0 \\
\hline Poorly differentiated usual mucinous adenocarcinoma & $3(6)$ & $2(67)$ & $2(67)$ & 0 \\
\hline Well differentiated intestinal type adenocarcinoma & $1(2)$ & 0 & $1(100)$ & 0 \\
\hline Well differentiated endometrioid adenocarcinoma & $2(4)$ & 0 & $2(100)$ & 0 \\
\hline Villoglandular mucinous adenocarcinoma & $1(2)$ & $1(100)$ & $1(100)$ & 0 \\
\hline Clear cells adenocarcinoma & $2(4)$ & $1(50)$ & $1(50)$ & 0 \\
\hline Signet ring cell mucinous adenocarcinoma & $2(4)$ & $2(100)$ & $1(50)$ & 0 \\
\hline Serous adenocarcinoma & $1(2)$ & 0 & $1(100)$ & $1(2)$ \\
\hline Well differentiated adenosquamous carcinoma & $8(16)$ & $6(75)$ & $6(75)$ & $1(2)$ \\
\hline Total & $50(100)$ & $31(62)$ & $40(80)$ & $5(10)$ \\
\hline
\end{tabular}

\section{Table 3 Immunohistochemical expression of CEA, Ki67 and p53 in ACa and MGH}

\begin{tabular}{lcccc}
\hline Markers & \multicolumn{2}{c}{$\begin{array}{c}\text { Adenocarcinoma (ACa) } \\
n=50 \text { cases }\end{array}$} & \multicolumn{2}{c}{$n=35$ cases } \\
& Positive cases & $(\%)$ & Positive cases & $(\%)$ \\
CEA & 31 & 62 & 0 & 0 \\
Ki67 & 40 & 80 & 3 & 8.6 \\
p53 & 5 & 10 & 0 & 0 \\
\hline
\end{tabular}

the effects of endogenous or exogenous hormones. On the other hand, Greeley et al.(13), in 1995, concluded that there was no statistically significant relationship between $\mathrm{MCH}$ and the use of the pill, and found $57.9 \%$ of the cases of $\mathrm{MGH}$ and $47.4 \%$ of the control (without MGH) associated to the influence of hormones.
The data gathered in our study is similar to that of the most recent publications ${ }^{(3,13)}$. The reduction in the number of cases of MGH related to the use of oral contraceptives might be explained by the modification of steroids and the considerable reduction of hormone dosage in the composition of the exogenous hormones currently used. 
Regarding the immunohistochemical study, $\mathrm{p} 53^{(21,28)}$ is a gene that codifies the $53 \mathrm{kD}$ protein (p53), present in all normal tissues where its mean life is very short, and does not accumulate in detectable levels. It acts on cellular proliferation, and by stopping the cellular cycle at $\mathrm{G1}$, it allows the repair mechanisms to act on the spontaneous or induced errors to the DNA. If these mechanisms fail, p53 can activate apoptotic events leading to the destruction of the damaged cell. This regulating effect appears to be inactivated by the mutations, which lead to altered protein formation, attributing proliferating properties to these cells. In the neoplasms of the cervix, p53 positivity is found in cervical adenocarcinoma, varying from $11 \%$ to $70 \%(16,17,21$, ${ }^{34)}$. According to our results, only $10 \%$ of the ACa showed positivity for $\mathrm{p53}$. However, literature also describes that not every cervical adenocarcinoma expresses $p 53(4,21,33)$ and its expression can be also found in florid $\mathrm{MGH}$ or tubal metaplasia( ${ }^{(4)}$. So, we can conclude that isolated, p53 expression would have little practical use in the differential diagnosis. Ki67 immunopositivity is confined to the nucleus in the division activity ${ }^{(15)}$. It marks a protein present in the cellular cycle in phases $\mathrm{S}, \mathrm{G} 2, \mathrm{M}$ and absent in $\mathrm{G} 0$, thus becoming a cellular proliferation marker. In the cervix, it presents limited expression to a few cells in normal glands and basal cells of the endocervical epithelium. However, it is diffusely distributed in CIN, especially in CIN 3 and in invasive adenocarcinoma ${ }^{(9,19)}$. Our cases showed Ki67 low expression in $\mathrm{MCH}$, interpreted as a low proliferation rate, not related to fast independent neoplastic growth of $\mathrm{ACa}$, which could also help in the differential diagnosis of more complex cases.
CEA is a high molecular weight glycoprotein associated to the cytoplasmatic membrane of tumor cells and which can be dosed in the blood stream ${ }^{(2,14)}$. It is an epithelium differential marker, and in the cervix, the monoclonal antibodies to the CEA isoantigens are frequently positive in adenocarcinoma and negative in the endocervical $\mathrm{MGH}^{(1,24,25,27,29,31)}$. In this sample, the lack of CEA expression in all cases of $\mathrm{MGH}$ agrees with the medical literature and points out to the absence of malignant epithelium differentiation. However, since some adenocarcinomas which did not express CEA were also found, the whole aspects such as morphological pattern, high Ki67 expression and clinical data have to be taken into account for the final diagnosis in these cases.

\section{Conclusions}

It can be concluded that $\mathrm{MGH}$ is a reactive type of glandular lesion, relatively common, found in about $15 \%$ of the cones in women of fertile age, around 35 years of age, different from $\mathrm{ACa}$ that occurs in older patients (mean: 53 years). MCH was related, in $50 \%$ of our cases, to the use of oral contraceptives or to physiological states with high hormone activity, such as pregnancy. Although its morphological characterization is often very easy, it can be difficult in variant forms, especially when a differential diagnosis with adenocarcinoma is necessary. Negative immunohistochemical reactions for p53, CEA and low positivity for Ki67 (less than $10 \%)$, define a characteristic profile for $\mathrm{MGH}$, which helps the differential diagnosis of the more problematic cases with the adenocarcinoma of the cervix.

\section{References}

I. BAMFORD, P. N. et al. An immunohistochemical study of the distribution of epithelial antigens in the uterine cervix. Obstet Gynecol, v. 6I, n. 5, p. 603-8, 1983.

2. BHAN, A. K. Diagnostic strategies based on differentiation antigens. In: COLVIN, R. B.; BHAN, A. K.; McCLUSKEY, R. T. (Eds.). Diagnostic Immunopathology. $2^{\text {nd }}$ ed. New York: Raven Press; 1995. p. 455-78.

3. CHUMAS, J. C. et al. Microglandular hyperplasia of the uterine cervix. Obstet Gynecol, v. 66, p. 406-9, 1985.

4. CINA, S. J. et al. Immunohistochemical staining for Ki67 antigen, carcinoembryonic antigen, and p53 in the differential diagnosis of glandular lesions of the cervix. Mod Pathol, v. 10, n. 3, p. 176-80, 1997.

5. COLLEMAN, D.V.; EVANS, D. M. D. Metaplastic, hyperplastic and reactive changes in cervical epithelium. In: COLLEMAN, D.V.; EVANS, D. M. D. Biopsy pathology and cytology of the cervix. $2^{\text {nd }}$ ed. London: Arnold; 1999. p 175-214.

6. DANIELE, E. et al. Micro-glandular hyperplasia of the uterine cervix. Histo-cytopathological evaluation, differential diagnosis and review of literature. Pathologica, v. 85, p. 607-35, 1993

7. De MAY, R. M. The art and science of Citopathology. Chicago:ASCP Press; 1995. p. 122-65.

8. GALL, S. A.; BOURGEOIS, C. H.; MAGUIRE, R. The morphologic effects of oral contraceptive agents on the cervix. JAMA, v. 207, p. 2243-47, 1969

9. GARZETTI, G. G. et al. MIB-I immunostaining in cervical intraepithelial neoplasia: prognostic significance in mild 
and moderate lesions. Gynecol Obstet Invest, v. 42, n. 4, p. 26I-6, 1996.

I0. GORODESKI, G. I. Estrogen increases the permeability of the human cervical epithelium by modulating cellular deformability. Am J Physiol, v. 275, n. 3, p. 888-99, 1998.

I I. GOVAN, A. D. T.; BLACK, W. P.; SHARP, J. L. Aberrant glandular polypi of uterine cervix associated with contraceptive pills: pathology and pathogenesis. J Clin Path, v. 22, p. 84-9, 1969

12. GRAHAM, J.; GRAHAM, R.; HIRABAYASHI, K. Reversible "cancer" and the contraceptive pill. Obstet Gynecol, v. 31 , p. 190-2, 1968.

13. GREELEY, C.; SCHROEDER, S.; SILVERBERG, S. G. Microglandular hyperplasia of the uterine cervix: a true pill lesion? Int J Gynecol Pathol, v. I4, p. 50-4, 1995.

14. HAMMARSTROM, S. The carcinoembryonic antigen (CEA) family: structures, suggested functions and expression in normal and malignant tissues. Semin Cancer Biol, v. 9, n. 2 p. 67-8I, 1999.

15. HEIDEBRECHT, H. J. et al. Monoclonal antibodies Ki-S3 and Ki-S5 yield new data on the Ki67 proteins. Cell Prolif, v. 29, n. 7, p. 4I 3-25, 1996.

16. HOLM, R. et al. Immunohistochemical analysis of p53 protein overexpression in normal premalignant, and malignant tissues of the cervix uteri.J Pathol, v. 169, n. I, p. 21-6, 1993.

17. HUNT, C. R. et al. p53 expression in carcinoma of the cervix.J Clin Pathol, v. 49, n. 12, p. 97।-4, 1996

18. KYRIAKOS, M.; KEMPSON, R. L.; KONIKOV, N. F. A clinical and pathologic study of endocervical lesions associated with oral contraceptives. Cancer, v. 22, p. 99- I 10, 1968.

19. LETEURTRE, E. et al. Importance of the study of the expression of MIB-I (Ki-67) for the diagnosis of endocervical glandular lesions. Ann Pathol, v. I8, p. 172-7, 1998.

20. MAQUEO, M.; AZUELA, J. C.; CALDERON, J. J. Morphology of the cervix in women treated with synthetic progestins. Am J Obstet Gynecol, v. 96, p. 994-8, 1966.

21. McCLUGGAGE, G. et al. Immunohistochemical detection of p53 and bcl-2 proteins in neoplastic and non-neoplastic endocervical glandular lesions. Int J Gynecol Pathol, v. 16, n. I, p. 22-7, 1997.

22. ROBBOY, S. J.; WELCH, W. R. Microglandular hyperplasia in vaginal adenosis associated with oral contraceptives and prenatal diethyl-stilbestrol exposure. Obstet Gynecol, v. 49 , p. 430-5, 1977.

23. SERRA, V. et al. Distribution of epithelial antigens in the human uterine cervix: a review. Arch Gynecol Obstet, v. 246, n. 2, p. 61-84, 1989.

24. SPEERS, W. C.; PICASO, L. G.; SILVERBERG, S. G. Immunohistochemical localization of carcinoembryonic antigen in microglandular hyperplasia and adenocarcinoma of the endocervix. Am J Clin Pathol, v. 79, n. I, p. 105-7, 1983.

25. STEEPER, T. A.;WICK, M. R. Minimal deviation adenocarcinoma of the uterine cervix ("adenoma malignum"). An immunohistochemical comparison with microglandular endocervical hyperplasia and conventional endocervical adenocarcinoma. Cancer, v. 58, n. 5, p. I|3|-8, 1986.

26. TAYLOR, H. B.; IREY, N. S.; NORRIS, H. J. Atypical endocervical hyperplasia in women taking oral contraceptives. JAMA, v. 202, n. 7, p. 637-9, 1967.

27. THOMPSON, J. A. Molecular cloning and expression of carcinoembryonic antigen gene family members. Tumour Biol, v. 16, n. I, p. 10-6, 1995.

28.THOR,A. D.; EDGERTON, S. M. Cellular markers of proliferation and oncogenes. In: COLVIN, R. B.; BHAN,A. K; McCLUSKEY, R. T. (Eds.). Diagnostic Immunopathology. $2^{\text {nd }}$ ed. New York: Raven Press; 1995. p. 669-84.

29. UEDA, S. et al. Immunohistochemical studies on carcinoembryonic antigen in adenocarcinomas of the uterus. Acta Pathol Jpn, v. 33, n. I, p. 59-69, 1983.

30.van HOEVEN, K.H.et al. Quantitative image analysis of MIB-I reactivity in inflammatory, hyperplastic, and neoplastic endocervical lesions. Int J Gynecol Pathol, v. I6, n. I, p. I5-21, 1997.

31. WELLS, M.; BROWN, L. J. R. Glandular lesions of the uterine cervix: the present state of our knowledge. Histopathology, v. 10, p. 777-92, 1986.

32. WILKINSON, E:; DUFOUR, F.; DUFOUR, D. R. Pathogenesis of microglandular hyperplasia of the cervix uteri. Obstet Gynecol, v. 47, p. 189-95, 1976.

33. YOON, H.; KIM, Y.; KANG, M. Human papillomavirus 16/18 expression of endocervical glandular lesions: relationship with p53 and MIB-I expressions. J Korean Med Sci, v. I6, p. |69-74, 2001.

34. YOUNG, R. H.; CLEMENT, P. B. Tumor-like lesions of the uterine cervix. New York: Churchill Livingstone; 1993. p. I-50.

35. ZAINO, R. J. Glandular lesions of the uterine cervix. Mod Pathol, v. I3, p. 26I-74, 2000.

36.ZAÑARTU,J. Effect of synthetic oral gestagens on cervical mucus and sperm penetration. Int J Fertil, v. 9, p. 225-30, 1964.
Endereço para correspondência

Liliana A. Lucci De Angelo Andrade Departamento de Anatomia Patológica Hospital das Clínicas, FCM/UNICAMP Cidade Universitária Zeferino Vaz, CP: 6111 CEP 13083-970 - Campinas-SP

Tel./Fax: (19) 3289-3897

e-mail: lucci@unicamp.br 